\title{
Development of obesity in parous women
}

\author{
R G NEWCOMBE \\ From the Department of Medical Statistics, Welsh National School of Medicine, Cardiff CF4 $4 X N$, UK
}

SUMMARY The relationship between obesity, age, and parity was studied in 35556 Cardiff resident parturients in the years 1965-79. The effects of age and parity on obesity were both real but were considerably confounded with each other. The aging effect differed among social classes while the effect of parity depended on smoking habits.

Obesity has adverse implications for physical fitness and quality of life and is a risk marker for future cardiovascular disease. While the major determinant of obesity is the balance between food intake, metabolism, and energy expenditure, the relationships with age and parity are commonly observed both between and within women.

There are great difficulties in ascertaining a representative population of women, and it is thus expedient to use attenders at clinics. A recent study from Finland ${ }^{1}$ was based on women participating in the Social Insurance Institution's multiphasic screening examination, most of whom had completed their families. A complementary approach is adopted in the present paper: the dependence of obesity in the non-pregnant state on age and parity is studied on a large sample of women attending antenatal clinics.

\section{Materials and methods}

The study was based on the data of the Cardiff Birth Survey. ${ }^{2}$ Women resident in Cardiff who delivered singletons during the period 1965-79 were included in the study, a total of 58755 deliveries. Maternal weight was recorded at 20 weeks' gestation, and a deducation of $4 \mathrm{~kg}(8.8 \mathrm{lb})$ was made to estimate normal prepregnant weight. ${ }^{3}$ To exclude cases in which abnormal weight gain at this stage was likely, attention was restricted to pregnancies in which the date of the last menstrual period was certain. It was demanded that height and weight and each of the explanatory variables-social class and smoking habits-should be known. These conditions excluded 17624 of the deliveries. Women having four or fewer previous deliveries, whose age at the index delivery was between 20 and 44, were included; higher parity and age groups were not included because the relatively small sample sizes might confuse the picture, while certain women under 20 will not have completed their normal growth. These conditions excluded a further 5575 deliveries, so that the resulting sample consisted of 35556 parturients.

Maternal weight was adjusted for height by using a formula $\mathrm{W}^{*}=\mathrm{W}\left(\mathrm{H}_{\mathrm{o}} / \mathrm{H}\right)^{\mathrm{k}}$. In this formula $\mathrm{H}$ and $\mathrm{W}$ demote the mother's height and estimated prepregnant weight. $\mathrm{H}_{\mathrm{o}}$ denotes a standard height of $1.60 \mathrm{~m}$ ( $5 \mathrm{ft} 3 \mathrm{in})$. For several values of $k$ a regression of $\mathrm{W}^{*}$ against $\mathrm{H}$ was carried out, in order to verify that $k=2$ was the optimal choice. Using this value of $k$, the mean value of $\mathrm{W}^{*}$ was then obtained for each of five groups defined by maternal age at delivery and five parity groups, and for age and parity cross-tabulated with each other and with smoking and social class. Regression coefficients of $\mathrm{W}^{*}$ with age and with parity were obtained, together with standard errors, and each combination of smoking and social class. The smoking variable was dichotomous, non-smokers and ex-smokers being contrasted with current smokers. The women were divided into four groups according to husband's social class: I and II, III, IV, and V, and an unmarried group.

\section{Results}

The correlation of $\mathrm{W}^{*}$ with $\mathrm{H}$ is $\mathbf{+ 0 . 0 8 2}$ when $k=1.5$ and -0.037 when $k=2$. The corresponding values of the regression coefficient are 130 and $-60 \mathrm{~g} / \mathrm{cm}$ respectively.

Using $\mathrm{k}=2$, the mean value of $\mathrm{W}^{*}$ among the 35556 women is $58.1 \mathrm{~kg}$, with a standard deviation of 8.9. Table 1 shows the mean value of $W^{*}$ for each combination of maternal age and parity. It is clear that $\mathrm{W}^{*}$ is related to age and parity independently and that these two effects are heavily confounded.

The crude gradient of $\mathrm{W}^{*}$ with age is $254 \mathrm{~g}$ increase a year, with a standard error of $10 \mathrm{~g}$. The corresponding regression coefficient pooled within parity groups is $198 \pm 11 \mathrm{~g} /$ year. Conversely, the 
Table 1 Mean prepregnant weight $(\mathrm{kg})$ adjusted to a height of $1.60 \mathrm{~m}$. Numbers in each cell are given in brackets. Marginal standard deviations are also given

\begin{tabular}{|c|c|c|c|c|c|c|}
\hline \multirow[b]{2}{*}{ Age of mother at delivery } & \multicolumn{5}{|c|}{ No of previous deliveries } & \multirow[b]{2}{*}{ Total } \\
\hline & 0 & $I$ & 2 & 3 & 4 & \\
\hline $20-24$ & $\begin{array}{l}56 \cdot 6 \\
(6682)\end{array}$ & $\begin{array}{l}56 \cdot 8 \\
(5089)\end{array}$ & $\begin{array}{l}57 \cdot 6 \\
(1686)\end{array}$ & $\begin{array}{c}58 \cdot 7 \\
(436)\end{array}$ & $\begin{array}{l}59 \cdot 8 \\
(76)\end{array}$ & $\begin{array}{l}56 \cdot 9 \pm 8 \cdot 8 \\
(13969)\end{array}$ \\
\hline $25-29$ & $\begin{array}{l}57 \cdot 2 \\
(3776)\end{array}$ & $\begin{array}{l}58 \cdot 0 \\
(4984)\end{array}$ & $\begin{array}{l}58 \cdot 7 \\
(2617)\end{array}$ & $\begin{array}{l}59 \cdot 0 \\
(1104)\end{array}$ & $\begin{array}{r}59.9 \\
(381)\end{array}$ & $\begin{array}{l}58 \cdot 1 \pm 8 \cdot 7 \\
(12862)\end{array}$ \\
\hline $30-34$ & $\begin{array}{l}58.4 \\
(1043)\end{array}$ & $\begin{array}{l}58.7 \\
(1951)\end{array}$ & $\begin{array}{l}59.9 \\
(1769)\end{array}$ & $\begin{array}{l}60.8 \\
(939)\end{array}$ & $\begin{array}{l}61 \cdot 3 \\
(448)\end{array}$ & $\begin{array}{c}59 \cdot 5 \pm 9 \cdot 1 \\
(6150)\end{array}$ \\
\hline $35-39$ & $\begin{array}{l}60 \cdot 2 \\
(304)\end{array}$ & $\begin{array}{l}59.6 \\
(520)\end{array}$ & $\begin{array}{l}60.7 \\
(595)\end{array}$ & $\begin{array}{l}61 \cdot 5 \\
(446)\end{array}$ & $\begin{array}{l}61.8 \\
(273)\end{array}$ & $\begin{array}{c}60 \cdot 7 \pm 9 \cdot 1 \\
(2138)\end{array}$ \\
\hline $40-44$ & $\begin{array}{l}61 \cdot 6 \\
(54)\end{array}$ & $\begin{array}{l}61 \cdot 8 \\
(72)\end{array}$ & $\begin{array}{c}61 \cdot 3 \\
(103)\end{array}$ & $\begin{array}{l}61 \cdot 6 \\
(116)\end{array}$ & $\begin{array}{l}62.7 \\
(92)\end{array}$ & $\begin{array}{c}61 \cdot 8 \pm 9 \cdot 4 \\
(437)\end{array}$ \\
\hline Total & $\begin{array}{l}57 \cdot 1 \pm 8 \cdot 3 \\
(11859)\end{array}$ & $\begin{array}{l}57 \cdot 7 \pm 8 \cdot 8 \\
(12616)\end{array}$ & $\begin{array}{l}59.0 \pm 9.3 \\
(6770)\end{array}$ & $\begin{array}{l}60.0 \pm 9.6 \\
(3041)\end{array}$ & $\begin{array}{l}61 \cdot 0 \pm 10.4 \\
(1270)\end{array}$ & $\begin{array}{l}58 \cdot 1 \pm 8 \cdot 9 \\
(35556)\end{array}$ \\
\hline
\end{tabular}

crude regression coefficient of $\mathrm{W}^{*}$ with parity is $981 \pm 44 \mathrm{~g}$ per delivery, which reduces to $650 \pm 47 \mathrm{~g}$ per delivery on adjustment for age using analysis of covariance. These regressions are all of very high statistical significance. For each of these analyses, the regression coefficients within subgroups defined by the adjusting variable do not differ significantly from one another, so that additivity of the effects of age and parity is acceptable.

The analysis summarised in table 1 was repeated for each combination of smoking and social class. Table 2 shows the rate of increase of $\mathrm{W}^{*}$ with age in each of these subgroups, parity being ignored. Margins contain weighted means of appropriate cell values. Two-way analysis of variance shows a very strong effect of social class on the aging gradient $(\mathrm{F}=12.45 ; \mathrm{df}=3,35540, \mathrm{p}<0.001)$, which is enhanced slightly on adjustment for smoking habits. The difference between the smoking groups was significant $(F=5.65, p<0.02)$ and became highly significant $(F=12.06, p<0.0001)$ on adjustment for sociomarital status. Table 3 shows the corresponding regression coefficients within parity groups. The effect of sociomarital status remains highly significant but the effect of smoking, with or without adjustment for sociomarital status, is not significant.

Table 4 shows the rate of increase of $\mathrm{W}^{*}$ with parity for each combination of smoking and social

Table 2 Rate of increase of weight in $g$ (adjusted for height) per year of age, together with standard error, by smoking habits and sociomarital status. No adjustment for parity

\begin{tabular}{llll}
\hline & $\begin{array}{l}\text { Non-smokers } \\
\text { and ex-smokers }\end{array}$ & $\begin{array}{l}\text { Current } \\
\text { smokers }\end{array}$ & Total \\
\hline Social classes & & & \\
$\quad$ I and II & $190 \pm 22$ & $190 \pm 43$ & $190 \pm 20$ \\
III & $280 \pm 17$ & $200 \pm 22$ & $250 \pm 13$ \\
IV and V & $430 \pm 31$ & $300 \pm 33$ & $370 \pm 23$ \\
Unmarried & $260 \pm 105$ & $400 \pm 105$ & $330 \pm 74$ \\
Total & $280 \pm 12$ & $230 \pm 17$ & $260 \pm 10$ \\
\hline
\end{tabular}

Table 3 Rate of increase of weight in $g$ (adjusted for height) per year of age, together with standard error, by smoking habits and sociomarital status. Computed within parity groups and pooled

\begin{tabular}{llll}
\hline & $\begin{array}{l}\text { Non-smokers } \\
\text { and ex-smokers }\end{array}$ & $\begin{array}{l}\text { Current } \\
\text { smokers }\end{array}$ & Total \\
\hline Social classes & & & \\
$\quad$ I and II & $120 \pm 24$ & $160 \pm 47$ & $130 \pm 22$ \\
III & $200 \pm 18$ & $180 \pm 24$ & $190 \pm 14$ \\
IV and V & $360 \pm 34$ & $300 \pm 37$ & $330 \pm 25$ \\
Unmarried & $200 \pm 109$ & $410 \pm 111$ & $300 \pm 78$ \\
Total & $200 \pm 13$ & $210 \pm 18$ & $200 \pm 11$ \\
\hline
\end{tabular}

Table 4 Rate of increase of weight in $g$ (adjusted for height) per delivery, together with standard error, by smoking habits and sociomarital status. Age ignored

\begin{tabular}{lllr}
\hline & $\begin{array}{l}\text { Non-smokers } \\
\text { and ex-smokers }\end{array}$ & $\begin{array}{l}\text { Current } \\
\text { smokers }\end{array}$ & Total \\
\hline Social classes & & & \\
I and II & $1030 \pm 107$ & $600 \pm 200$ & $940 \pm 94$ \\
III & $1350 \pm 75$ & $430 \pm 94$ & $990 \pm 59$ \\
IV and V & $1370 \pm 136$ & $540 \pm 138$ & $960 \pm 97$ \\
Unmarried & $1970 \pm 525$ & $480 \pm 387$ & $1000 \pm 312$ \\
Total & $1270 \pm 56$ & $480 \pm 71$ & $970 \pm 44$ \\
\hline
\end{tabular}

class, ignoring age. The effect of smoking is highly significant $(F=77.29, p<0.001)$ and is increased slightly on adjustment for sociomarital status; the effect of social class is not significant. The corresponding figures computed and pooled within quinquennial age groups appear in table 5, which

Table 5 Rate of increase of weight in $g$ (adjusted for height) per delivery, together with standard error, by smoking habits and sociomarital status. Computed within quinquennial age groups and pooled

\begin{tabular}{lrrr}
\hline & $\begin{array}{l}\text { Non-smokers } \\
\text { and ex-smokers }\end{array}$ & $\begin{array}{l}\text { Current } \\
\text { Smokers }\end{array}$ & Total \\
\hline Social classes & & & \\
$\quad$ I and II & $790 \pm 117$ & $280 \pm 219$ & $680 \pm 103$ \\
III & $1000 \pm 82$ & $90 \pm 102$ & $650 \pm 64$ \\
IV and V & $710 \pm 148$ & $0 \pm 152$ & $370 \pm 106$ \\
Unmarried & $1790 \pm 543$ & $90 \pm 408$ & $710 \pm 326$ \\
Total & $910 \pm 61$ & $90 \pm 78$ & $600 \pm 48$ \\
\hline
\end{tabular}


shows a similar pattern. The age-adjusted parity gradient in smokers is not significantly different from zero, whether based on all smokers or within any social group.

\section{Discussion}

In the formula $\mathrm{W}^{*}=\mathrm{W}\left(\mathrm{H}_{\mathrm{o}} / \mathrm{H}\right)^{\mathbf{k}}$ the choice of $\mathrm{k}$ to make $\mathrm{W}^{*}$ uncorrelated with $\mathrm{H}$ was a little under 2 , in agreement with the results of Billewicz et al $^{4}$ for pregnant women and Khosla and Lowe ${ }^{5}$ for men. The deduction of $4 \mathrm{~kg}$ to assess normal non-pregnant weight is appropriate since the aim of the study is to examine a chronic problem that extends beyond the short-term effects of pregnancy. The exclusion of multiple pregnancies and of those with uncertain dates is likely to be important, in that these conditions could give rise to differences in weight gain as great as the differences between age and parity groups compared.

Heliovaara and Aromaa ${ }^{1}$ have shown independent effects of age and parity on obesity among 15626 Finnish women who have mostly completed their reproductive histories. The present study complements these results using women of childbearing ages. Age and parity effects are considerably confounded with each other, but both exist. They explain a significant albeit small part of the variation in obesity index between women. They are not accounted for by confounding with social class or smoking in the index pregnancy.

The effects shown in tables 2 to 5 , which may be regarded as heterogeneity of gradients or as interactions-for instance, age/social class interaction-are of interest. It could be conjectured that the upwards trend in weight with aging, after adjusting for the effects of childbirth, depends on the quality of the diet and general life style (represented by social class) rather than the quantity eaten (influenced by smoking); on the other hand, smokers do tend to lose their extra weight after delivery whereas non-smokers, in whom the appetite is not depressed, do not. Such interaction effects may, however, be artefactual: while successive cohorts of women have been more prone to smoke, non-smokers of a given parity are likely to be older than smokers of the same parity.

The method of feeding in the index pregnancy was also examined to serve as a marker for feeding in previous pregnancies. The regression coefficient of $\mathrm{W}^{*}$ on parity was $1150 \mathrm{~g}$ per delivery in breast feeders and $880 \mathrm{~g}$ in those who used artificial feeding throughout, reflecting the tendency for breast feeding to be associated with greater weight gain.

It must be conceded that the present study has several limitations, in terms of both computational accuracy and ascertainment of the data. Five-year age intervals lead to a relatively crude assessment of aging effects. To compensate for the lack of more precise information from the Cardiff Birth Survey, information on age in single years based on 300228 deliveries to women aged 20-44 in 1968-70 in Sweden $^{6}$ was used. The Swedish parturients were slightly older (8.1\% being $35-44,16 \cdot 5 \% 30-34)$ than the Cardiff women $(7 \cdot 2 \% 35-44,17 \cdot 3 \% 30-34)$, no doubt because of the decreasing trend in age at birth; the differences were judged to be slight enough to allow mean maternal ages within each quinquennium based on Swedish single-year data, 22.23, 26.73, $31 \cdot 64,36 \cdot 62$, and $41 \cdot 24$, to apply to the Cardiff data. Using these instead of mid-interval ages, the aging gradient was enhanced from $254 \mathrm{~g}$ to $268 \mathrm{~g}$ a year, so that all stated age gradients are likely to be underestimates by around $5 \%$.

The study population consists of pregnant women and thus does not constitute a random sample of all the women in the population of appropriate age and parity. A random sample of a defined population of women would form an ideal basis for study, but it is unlikely that the co-operation of a sufficiently large and representative subgroup would be obtained; besides, considerable resources would be required if such a study were carried out on an ad hoc basis. It is assumed that weight gain in the first half of pregnancy is independent of age and parity. Certain of the criteria for inclusion in the study were designed to exclude cases in which a lower weight gain was likely. Unfortunately, it is not possible to link on a sufficiently comprehensive basis successive pregnancies in the same woman as recorded by the Cardiff Birth Survey, since hospital number and surname may change between successive deliveries and the mother's own date of birth and maiden name were not coded; otherwise this would have been an informative, complementary approach. Assumptions of statistical independence of the cases studied are violated in that the same women may appear several times at different parities in the study. It is unlikely that any qualitiative distortion of the results has resulted. The regressions would remain highly significant if a much lower nominal sample size, such as 10000 , were assumed.

\section{References}

${ }^{1}$ Heliövaara M, Aromaa A. Parity and obesity.J Epidemiol Community Health 1981; 35: 197-9.

${ }^{2}$ Andrews J, Davies K, Chalmers I, Campbell H. The Cardiff birth survey: development, perinatal mortality, birth weight and length of gestation. In: Harper PS, Sunderland $\mathrm{E}$, eds. Genetic and population studies in Wales. Cardiff: University of Wales Press, 1982. 
${ }^{3}$ Thomson AM, Billewicz WZ. Height, weight and food intake in man. Br J Nutr 1961; 15: 241-52.

'Billewicz WZ, Kemsley WFF, Thomson AM. Indices of adiposity. Br J Prev Soc Med 1962; 16: 183-8.

${ }^{5} \mathrm{Khosla} T$, Lowe CR. Indices of obesity derived from body weight and height. Br J Prev Soc Med 1967; 21: 122-8.
${ }^{6}$ Hook EB, Lindsjö A. Down syndrome in live births by single year maternal age interval in a Swedish study; comparisons with results from a New York State study. Am J Hum Genet 1978; 30: 19-27. 